\title{
Inheritance of the efficiency of nitrogen uptake and utilization in winter wheat (Triticum aestivum L.) under diverse nutrition levels
}

\author{
Andrzej G. Górny • Zofia Banaszak • \\ Bogumila Lugowska · Dominika Ratajczak
}

Received: 30 November 2009/ Accepted: 15 July 2010/Published online: 29 July 2010

(C) The Author(s) 2010. This article is published with open access at Springerlink.com

\begin{abstract}
The effects of contrasting soil nitrogen (N) levels on the inheritance of the efficiency of $\mathrm{N}$ uptake and $\mathrm{N}$ utilization in grain mass formation were examined in winter wheat. Parents of various origins and their diallel $\mathrm{F}_{2}$-hybrids were evaluated in field and pot experiments under varying levels of soil $\mathrm{N}$. The range of additive variance in the components of $\mathrm{N}$ efficiency was narrow, especially under $\mathrm{N}$ shortage. The soil N-treatments imposed had a substantial influence on gene actions responsible for the efficiency components and modes of inheritance. Genotype $x$ nutrition interactions were common. Under high $\mathrm{N}$-fertilization, the efficiency components were inherited in a manner favourable for wheat selection (preponderance of additive effects). However, the enhanced contribution of non-additive gene effects and increased dominance under $\mathrm{N}$-limited conditions could impede wheat selection to improve the $\mathrm{N}$ efficiency and adaptation to less luxurious fertilization regimes. Selection methods that eliminate masking non-additive influences and take advantage of the additive variance should be employed to improve these traits.
\end{abstract}

A. G. Górny $(\bowtie) \cdot$ D. Ratajczak

Institute of Plant Genetics, Polish Academy of Sciences, Strzeszyńska 34, 60-479 Poznań, Poland

e-mail: agor@igr.poznan.pl

Z. Banaszak · B. Ługowska

Danko Plant Breeding Ltd., Choryń, 64-005 Racot, Poland
Keywords Adaptation - Combining ability · Low-input breeding

\section{Introduction}

There are essential economic and ecological grounds for which the major systems of cereal production are tending to shift towards sustainable agriculture and/or more optimal input technologies. Hence, increased interest is being shown worldwide in cultivars that are more efficient in utilizing soil resources and better fitted to water and nutrient limitations (El Bassam 1998; Good et al. 2004; Fageria and Baligar 2005; Phillips and Wolfe 2005; Muurinen et al. 2006; Hirel et al. 2007; Lammerts van Bueren et al. 2008; Sylvester-Bradley and Kindred 2009). Among cereals, hexaploid winter wheat (Triticum aestivum L.) is commonly identified as a species with higher requirements for nutrients, especially nitrogen. Thus, breeding wheat cultivars with improved adaptation to less favourable, but more optimised $\mathrm{N}$ fertilization regimes has gained importance. In Poland, like in other European countries with prevailing podzolic soils, such breeding strategies are also justified by periodic droughts and/or nitrogen and phosphorus imbalances that are major constraints limiting grain production.

The efficiency of nitrogen use (NUE; defined here as the grain yield per unit of the soil $\mathrm{N}$ ) and plant adaptation to less favourable nutrition regimes is complex with various endo- and exogenous mechanisms 
involved (Duncan and Baligar 1990; Sattelmacher et al. 1994; Marschner 1995; Gastal and Lemaire 2002; Lawlor 2002; Martre et al. 2003; Coque and Gallais 2007; Hirel et al. 2007). Different morphophysiological characteristics, associated with both the uptake capacity (NUpE; defined here as a proportion of total $\mathrm{N}$ uptake to $\mathrm{N}$ availability in the soil) and efficiency of nitrogen utilization in grain mass formation (NUtE; defined here as the grain mass formed per unit of $\mathrm{N}$ absorbed), appear to be critical components of NUE (Moll et al. 1982; Huggins and Pan 2003). Although numerous reports on genotypic variation in components of $\mathrm{N}$ efficiency already suggest potential applications of this genetic knowledge for wheat improvements (Dhugga and Waines 1989; Le Gouis and Pluchard 1996; Ortiz-Monasterio et al. 1997; El Bassam 1998; Le Gouis et al. 2000; Oracka et al. 2000; Górny et al. 2006a; Laperche et al. 2006a; Kichey et al. 2007; Baresel et al. 2008; Barraclough et al. 2010), relatively fewer attempts have been made to breed wheat for these traits (Van Ginkel et al. 2001; Brancourt-Hulmel et al. 2005; Löschenberger et al. 2008; Wolfe et al. 2008).

Progress in breeding winter wheats better adapted to less favourable fertilization regimes and/or lowinput/organic agricultural systems is still restricted for several reasons. Wheat breeders are frequently sceptical not only because of the morpho-physiological complexity of the matter, but mainly due to limited data on both the variation among available wheat collections and the genetics of key characters involved. Hence, several important queries remain to be resolved, especially in regard to the most effective selection schemes, desirable plant ideotypes for lowinput ecosystems, appropriate selection criteria and features of the selection environment or cropping systems necessary for such breeding programs (e.g. Ceccarelli 1996; Dawson et al. 2008; Wolfe et al. 2008). Furthermore, modern European wheat cultivars are phenotypically different but, in essence, represent a limited gene pool. The majority of them were developed under favourable or even luxurious fertilization regimes used at most breeding stations without or with scarce selection pressure for components of nutrient use efficiency. On the contrary, beneficial plant characteristics for low-input ecosystems may be different from those present in modern, high-yielding wheats (El Bassam 1998; Murphy et al. 2007). This raises concerns for breeders as to whether the range and spectrum of genetic variation in nutrient efficiency among modern wheat cultivars is sufficiently wide under sub-optimal habitats to guarantee progress in breeding more efficient wheats better adapted to less favourable fertilization practices.

The manner in which target traits are inherited has, of course, major consequences for the whole breeding strategy. However, our understanding of the inheritance of the morpho-physiological components of $\mathrm{N}$ efficiency in wheat, as in other cereals, is still extremely limited. There is some information regarding various characteristics decisive for the uptake efficiency in juvenile wheat plants (Gamzikova 1992; An et al. 2006; Górny et al. 2006b; Laperche et al. 2006b), but the limited data may lead to uncertain conclusions on $\mathrm{N}$ efficiency over the whole growing season. However, the genetic control of whole-season $\mathrm{N}$ efficiency has rarely been examined in wheat. Recent extensive molecular studies (Charmet et al. 2005; Quarrie et al. 2005; Habash et al. 2007; Laperche et al. 2008; Fontaine et al. 2009) identified numerous genome regions (QTLs) responsible for grain yield structure and nitrogen yield under $\mathrm{N}$ limitations, grain protein content and $\mathrm{N}$ metabolism in the uppermost foliage as well as for the activity of glutamine synthetase and glutamate dehydrogenase, the key enzymes involved in $\mathrm{N}$ assimilation. In earlier investigations (Le Gouis et al. 2002), both additive and non-additive genetic effects were crucial for agronomic NUE components in $F_{1}$ hybrids between modern French cultivars. In contrast, additive gene action was only important for NUE components among $F_{2}$ progenies of wheats of Turkish origin (Yildirim et al. 2007). To the best of our knowledge, however, no information exists in wheat for the major physiological measures of $\mathrm{N}$ efficiency, i.e. the uptake and utilization efficiencies (NUpE and NUtE) when whole-season indices and conventional genetic/ breeding approaches are considered, and this may have an impact on current breeding methods, aspirations and goals.

Thus, the main objectives of this field and greenhouse study were (i) to assess the modes by which NUpE and NUtE are inherited, and (ii) to evaluate effects of varied nutrition on gene action. For these purposes, hybrids between cultivars representative of old and modern wheat germplasm of various origins were evaluated under diverse $\mathrm{N}$ fertilization regimes. 


\section{Materials and methods}

Plant materials

A diallel excluding reciprocal crosses was made among six representative winter wheat cultivars, viz. Mironovska 808 (old Ukrainian cv., released in 1962; hereafter referred to as Mironovska), Maris Huntsman (old British cv., 1968), Korweta and Finezja (modern Polish cvs., 2000/2002), and Clever and Kris (modern, short-statured British cvs., 1999/2001). The parents were known to exhibit distinct differences in yield potential/stability, rooting capacity, photosynthetic activity of leaves and nutrient efficiency in response to water and nutrient shortages (e.g. Górny and Garczyński 2002; Górny et al. 2004, 2006a, b, and unpubl.). Most of them are actually accepted by national wheat breeders as donors of different qualitative and quantitative plant characteristics. After reproduction of parental lines and $\mathrm{F}_{1} \mathrm{~s}$ under uniform conditions, the parents and their $F_{2}$ hybrids were studied during 2005-2008 at different field locations and in a greenhouse pot-experiment under varied $\mathrm{N}$ fertilization regimes.

\section{Field experiment}

The trials were carried out in 2005 and 2007 at two locations, i.e. on experimental fields of the Danko Plant Breeding Ltd. in Choryń, Poland (2005; a superior location; brown podzolic soils classified as domestic IIIa class with a moderately high content of plant-available $\mathrm{N}$ in the soil A-horizon; usually about $45 \mathrm{ppm} \mathrm{N}$ ) and at the Institute of Plant Genetics in Poznań, Poland (2007; a poor location; typical sandloamy podzolic soils classified as domestic IVb/V class with a reduced $\mathrm{N}$ content, i.e. $<15 \mathrm{ppm} \mathrm{N}$ in the A-horizon; by a modified Spurway's method; Nowosielski 1974). There were favourable weather conditions in 2005, whereas low temperatures during the first $6 / 7$ weeks of spring growth in 2007 , followed by hot weather and rainfall deficits until the middle grain filling phase, did not favour plant growth.

The experimental fields in Choryń and Poznań were managed under conditions representative of typical high- and low-input farming, respectively, in the region. Before experimentation, fields were limed as required and established following a rotation with $\mathrm{N}$-fertilized (40 and $32 \mathrm{~kg} \mathrm{~N} / \mathrm{ha}$, respectively) preceding winter crops, i.e. rape in Choryń and rye with vetch + fallow (3 months) in Poznań. After the green-manured fore-crops, mean $\mathrm{N}$ contents in the soil A-horizon were 63 ppm (in Choryń) and 39 ppm (in Poznań), respectively. During the weeks prior to sowing, major and minor elements were added as necessary to achieve their optimal levels in the soil. Nitrogen was added at different rates to discriminate both locations for the plant-available N. In Choryń, a high rate $\left(140 \mathrm{~kg} \mathrm{ha}^{-1}\right)$ of $\mathrm{N}$ fertilizer (as ammonium nitrate) was used, whereas in Poznań a reduced $\mathrm{N}$ rate $\left(85 \mathrm{~kg} \mathrm{ha}^{-1}\right)$ was applied. At each location, nitrogen was top dressed in three sub-rates (before sowing: at middle tillering: before heading; 15:55:30; by $\%$ of the total $\mathrm{N}$ rate) as commonly recommended. In total, $29.75 \mathrm{~g} \mathrm{~N}$ and $18.25 \mathrm{~g} \mathrm{~N}$ per square meter were available for plants in the soil A-horizon in Choryń and Poznań, respectively.

At each location, the trials were arranged as randomised complete blocks with 21 entries (parents and $\mathrm{F}_{2} \mathrm{~s}$ ) and five replications. Plots were 2-m long and consisted of six rows spaced $16 \mathrm{~cm}$ apart. Materials were drill-seeded at optimum sowing dates with rates of about 350 seeds per $\mathrm{m}^{2}$. Standard chemical treatments were used to control weeds, insects and pathogens. If necessary, some trace elements (as chelates; Librel B, CIBA Ltd.) were also applied to the plant foliage. No growth regulators were used, but due to increased height of older parents and their progenies, at the end of the vegetative growth phase a commercial fishnet (mesh $20 \times 20 \mathrm{~cm}$; ZSR Korsze Ltd., PL) was extended over the plots to eliminate lodging during the generative growth phase.

\section{Pot experiment}

A factorial experiment was arranged as a completely randomised design with 21 entries $\left(\mathrm{Ps}\right.$ and $\mathrm{F}_{2} \mathrm{~s}$ ), two soil $\mathrm{N}$ treatments, four pot-replications and 14 plants per pot. Using the procedure described by Górny (1999), plants were grown from November to June in double-walled Kick-Brauckman's experimental pots in a partly conditioned greenhouse. Pots $(23 / 21 \mathrm{~cm}$ in diameter, $27 \mathrm{~cm}$ high) were uniformly filled with $9 \mathrm{dm}^{3}$ of a sieved soil mixture (loamy-sand soil: commercial peat, 1:2, by v/v, $\mathrm{pH}$ 6.4) of an optimal moisture (70\% of field capacity), previously limed as required, incubated for 2 months and mechanically mixed with water-soluted nutrients to achieve optimal/required 
macro-nutrient contents and standard concentrations of microelements. As monitored by a modified Spurway's method, concentrations of plant-available macro- and micronutrients in the initial soil substrate were as follows: $80 \mathrm{~N}, 150 \mathrm{P}, 250 \mathrm{~K}, 130 \mathrm{Mg}$ $\left(\mathrm{mg} \mathrm{dm}^{-3}\right)$ and $85 \mathrm{Fe}, 6 \mathrm{Zn}, 4.5 \mathrm{Cu}, 25 \mathrm{Mn}$ and $0.8 \mathrm{~B}$ (ppm).

Fourteen uniform, surface-sterilized and slightly pre-germinated seeds (filter paper, $24 \mathrm{~h}, 22^{\circ} \mathrm{C}$ ) were sown in pots (approx. density 350 seeds $\mathrm{m}^{-2}$ ). After the 1 st leaf emergence, the soil surface was covered with a $2.5-\mathrm{cm}$ layer of perlite to eliminate soil water evaporation (E). Check pots without plants were included to record potential E. Subsequently, the pot-grown plants were vernalized at $1-5^{\circ} \mathrm{C}$ for 8 weeks. Later, depending on the growth stage and photoperiod cycling, $8-28 / 6-18^{\circ} \mathrm{C}$ day/night mean temperatures, $10-18 \mathrm{~h}$ photoperiod and $50-85 \% \mathrm{RH}$ were maintained. To prolong the natural light duration during respective growth stages, an artificial lighting system was provided supplying at least 400-800 $\mu \mathrm{mol}$ PAR $\mathrm{m}^{-2} \mathrm{~s}^{-1}$ at the plant level as ensured by enhanced density $\left(1000 \mathrm{~W} \mathrm{~m}^{-2}\right)$ of high-pressure sodium- and mercury-lamps (both $400 \mathrm{~W}$ ). To minimize possible effects of light and temperature gradients, pots were frequently moved around the experimental area. As described elsewhere (Górny and Garczyński 2002), the amount of water transpired was recorded by frequent weighing of pots (2- to 7-times per week, depending upon the growth phase), and the initial soil moisture (70-75\% FWC) was maintained during the whole plant vegetation by addition of deionised water into pots. The following soil $\mathrm{N}$ treatments were used: (1) High $\mathrm{N}$-increased $\mathrm{N}$ content in the soil, i.e. $235 \mathrm{mg} \mathrm{N} \mathrm{dm}{ }^{-3}$ soil (excluding initial $\mathrm{N}$ concentrations), and (2) Low $\mathrm{N}$-reduced $\mathrm{N}$ content in the soil, i.e. $140 \mathrm{mg} \mathrm{N} \mathrm{dm}^{-3}$. In each treatment, nitrogen (as ammonium nitrate) was added in two water-soluted sub-portions: at tillering ( $65 \%$ of the whole rate) and before heading (35\% of the whole rate). Totals of $2.84 \mathrm{~g}$ and $1.98 \mathrm{~g} \mathrm{~N}$ in each pot were available for plants in the high and low $\mathrm{N}$ treatments, respectively.

\section{Data collection}

Whole plants were hand-harvested at full maturity. The vegetative (stems + leaves) and generative (grains) plant parts were separated and their dry weights $\left(\mathrm{g} \mathrm{m}^{-2}\right.$ or $\mathrm{g} \mathrm{pot}^{-1}$ ) were determined by oven drying at $65^{\circ} \mathrm{C}$ for $72 \mathrm{~h}$. Nitrogen concentrations (grain $\mathrm{N} \%$ and straw $\mathrm{N} \%$ ) in the dried and ground homogeneous sub-samples of the parts (IKA mill processed) were measured using high-temperature combustion (Dumas' method) in the elemental analyser (VarioMax-CN, Elementar Ltd., Germany) calibrated using standardized reference leaf and grain flour samples (LECO Ltd., Poland). Using the grain and straw $\mathrm{N}$ concentrations, nitrogen uptake (NUp, $\mathrm{g} \mathrm{m}^{-2}$ or $\mathrm{g} \mathrm{pot}^{-1}$ ), i.e. total amounts of $\mathrm{N}$ taken up by plants as a sum of $\mathrm{N}$ accumulated in vegetative parts and grains, were estimated. According to Moll et al. (1982), the following components of $\mathrm{N}$ efficiency were determined:

- $\mathrm{NUpE}(\%)$; $\mathrm{N}$ uptake efficiency $=(\mathrm{NUp} / \mathrm{N}$ available in the soil) $\times 100$,

- $\mathrm{NHI}(\%)$; $\mathrm{N}$ harvest index $=(\mathrm{N}$ accumulated in grains/NUp) $\times 100$,

- $\mathrm{Gw} / \mathrm{Ng}\left(\mathrm{mg} \mathrm{mg}^{-1}\right)$; grain dry weight produced per unit of $\mathrm{N}$ accumulated in grains,

- NUtE $\left(\mathrm{g} \mathrm{g}^{-1}\right)$; Gw/NUp ratio, i.e. physiological index of the efficiency of $\mathrm{N}$ utilization in grain mass formation (syn. $\mathrm{N}$ utilization efficiency ratio).

\section{Data analysis}

Standard statistical methods were used for data evaluations. The analysis of variance (ANOVA) was performed on the basis of individual plot and/or pot observations (MSTAT-C package, University of Michigan, 1990). Means were compared using Duncan's multiple range tests. Variance components, genetic parameters and general (GCA) and specific (SCA) combining abilities were estimated according to the Hayman, Griffing and Mather and Jinks concepts for diallel mating designs as detailed by Singh and Chaudhary (1979) and Kala et al. (1994). In the analysis, least-squares estimates of the genetic components of variance were evaluated. In this additive-dominance model, the genetic components are $D$, which measures additive effects, while $H I$ and $H 2$ measure only dominance effects; $H 1<H 2$ indicates unequal $p$ and $q$ allele frequencies at the relevant loci. In turn, $h 2 / H 2$ is an approximate measure of the number of groups of genes exhibiting dominance, whereas $F$ determines the relative frequency of dominant and recessive alleles. A positive value of 
$F$ indicates that there are more dominant alleles present in the parental lines than recessive ones, irrespective of whether or not these have increasing or decreasing effects on the character examined. In $\mathrm{F}_{2}$, the quantity $(1 / 4 H I / D)^{1 / 2}$ is a weighted estimate of the average degree of dominance at each locus, while the ratio $\left(1 /{ }_{4} D\right) /\left(1 / 4 D+1 / 16 H 1-1 /{ }_{8} F+E\right)$ defines the proportion of additive and/or additive $\times$ additive genetic variance to the total phenotypic variance, i.e. the narrow-sense heritability of a character.

Using a slight modification of the methodology proposed by Fageria and Baligar (1993, 1997), the parents and hybrids were categorized for their yielding capacity under low $\mathrm{N}$ fertilization and NUtE-response index (NUtE-RI), i.e. a measure of the physiological ability to utilize each additional amount of absorbed $\mathrm{N}$ with an enhanced efficiency. NUtE-RI was defined as the (grain dry weight under high $\mathrm{N}$ - grain dry weight under low $\mathrm{N}) /(\mathrm{N}$ uptake under high $\mathrm{N}-\mathrm{N}$ uptake under low $\mathrm{N}$ ) ratio. In addition, the entries were also grouped depending upon the NUtE-RI and level of tolerance to low $\mathrm{N}$
(T). Tolerance index was determined for each $i$ th entry on the basis of its grain yield (d.w. $\mathrm{m}^{-2}$ ) using a modification of the standard equation (Fischer and Maurer 1978): $\mathrm{T}=\left(\mathrm{L}_{i} / \mathrm{H}_{i}\right) / \mathrm{D}$, where $\mathrm{L}_{i}$ and $\mathrm{H}_{i}$ are the grain yields of the $i$ th entry under low and high $\mathrm{N}$ nutrition, respectively, while D-value (=overall mean L/overall mean $\mathrm{H}$ ) is a general measure of stress intensity in the experiment.

\section{Results and discussion}

Variation of characters

In both experiments, significant differences in $\mathrm{N}$ uptake efficiency (NUpE) and $\mathrm{N}$ utilization efficiency (NUtE) were found among the parents and their $\mathrm{F}_{2^{-}}$ hybrids (Table 1). In general, $F_{2}$-means for most characters were within the range of parental lines. Under field conditions, some $\mathrm{F}_{2}$-progenies exhibited enhanced $\mathrm{N}$ uptake efficiency and/or an increased ability to produce more grain dry weight per unit of $\mathrm{N}$
Table 1 Variation ranges (minimal and maximal means) among parental and hybrid generations, average treatment effects, summarized results of the pooled analysis of variance and broad-sense

heritabilities $\left(\mathrm{h}_{\mathrm{BS}}^{2}\right)$ for $\mathrm{N}$ uptake efficiency (NUpE), nitrogen harvest index (NHI), grain dry weight production per grain $\mathrm{N}$ unit (Gw/Ng) and $\mathrm{N}$ utilization efficiency ratio (NUtE) of winter wheat in the field and pot experiment ns, ***-non-significant and significant at $P=0.05$ and $P=0.01$, respectively

\begin{tabular}{|c|c|c|c|c|c|c|c|c|}
\hline \multirow[t]{3}{*}{$\begin{array}{l}\text { Variation } \\
\text { source }\end{array}$} & \multirow{2}{*}{\multicolumn{2}{|c|}{$\begin{array}{l}\begin{array}{l}\text { Uptake } \\
\text { efficiency }\end{array} \\
\text { NUpE }\end{array}$}} & \multicolumn{6}{|c|}{ Utilization efficiency } \\
\hline & & & \multicolumn{2}{|l|}{ NHI } & \multicolumn{2}{|l|}{$\mathrm{Gw} / \mathrm{Ng}$} & \multicolumn{2}{|l|}{ NUtE } \\
\hline & $\begin{array}{l}\text { Field } \\
(\%)\end{array}$ & $\begin{array}{l}\text { Pots } \\
(\%)\end{array}$ & $\begin{array}{l}\text { Field } \\
(\%)\end{array}$ & $\begin{array}{l}\text { Pots } \\
(\%)\end{array}$ & $\begin{array}{l}\text { Field } \\
\left(\mathrm{mg} \mathrm{mg}^{-1}\right)\end{array}$ & $\begin{array}{l}\text { Pots } \\
\left(\mathrm{mg} \mathrm{mg}^{-1}\right)\end{array}$ & $\begin{array}{l}\text { Field } \\
\left(\mathrm{g} \mathrm{g}^{-1}\right)\end{array}$ & $\begin{array}{l}\text { Pots } \\
\left(\mathrm{g} \mathrm{g}^{-1}\right)\end{array}$ \\
\hline \multicolumn{9}{|l|}{ Entries } \\
\hline \multicolumn{9}{|l|}{ Parents } \\
\hline $\min$ & 65.9 & 58.0 & 79.4 & 72.8 & 42.1 & 29.5 & 33.8 & 21.6 \\
\hline $\max$ & 71.3 & 74.7 & 85.7 & 79.9 & 46.3 & 32.8 & 39.7 & 25.8 \\
\hline \multicolumn{9}{|l|}{$\mathrm{F}_{2}$ hybrids } \\
\hline $\min$ & 63.3 & 56.6 & 79.3 & 74.7 & 40.1 & 30.1 & 33.1 & 22.9 \\
\hline $\max$ & 80.2 & 72.4 & 86.0 & 81.2 & 49.0 & 33.6 & 41.0 & 26.4 \\
\hline $\operatorname{Lsd}_{0.05}$ & 8.3 & 5.4 & 2.3 & 2.2 & 2.4 & 1.7 & 2.0 & 1.4 \\
\hline \multicolumn{9}{|l|}{ Treatments } \\
\hline High N & 66.3 & 60.5 & 79.5 & 75.2 & 44.7 & 30.6 & 35.5 & 23.0 \\
\hline Low $\mathrm{N}$ & 75.9 & 66.9 & 86.1 & 79.6 & 44.0 & 33.3 & 37.9 & 26.5 \\
\hline $\operatorname{Lsd}_{0.05}$ & 2.6 & 1.6 & 0.7 & 0.7 & ns & 0.5 & 0.6 & 0.4 \\
\hline \multicolumn{9}{|l|}{ ANOVA } \\
\hline Entries (E) & $* *$ & $* *$ & $* *$ & $* *$ & $* *$ & $* *$ & $* *$ & $* *$ \\
\hline $\begin{array}{l}\text { Treatments } \\
(\mathrm{T})\end{array}$ & $* *$ & $* *$ & $* *$ & $* *$ & $\mathrm{~ns}$ & $* *$ & $* *$ & $* *$ \\
\hline $\mathrm{E} \times \mathrm{T}$ & $* *$ & $* *$ & $* *$ & $* *$ & $* *$ & $* *$ & $* *$ & ns \\
\hline $\mathrm{h}_{\mathrm{BS}}^{2}$ & 0.32 & 0.74 & 0.59 & 0.55 & 0.45 & 0.56 & 0.58 & 0.81 \\
\hline
\end{tabular}


Fig. 1 Relationships between the grain $\mathrm{N}$ concentration $(\%)$ and $\mathrm{N}$ utilization efficiency $\left(\mathrm{g} \mathrm{g}^{-1}\right)$ in the field-grown parents (open circle, open square) and $\mathrm{F}_{2}$ hybrids (filled circle, filled square) under high $\mathrm{N}$ (in Choryń 2005; circles) and low $\mathrm{N}$ (in Poznań 2007; squares) conditions, respectively

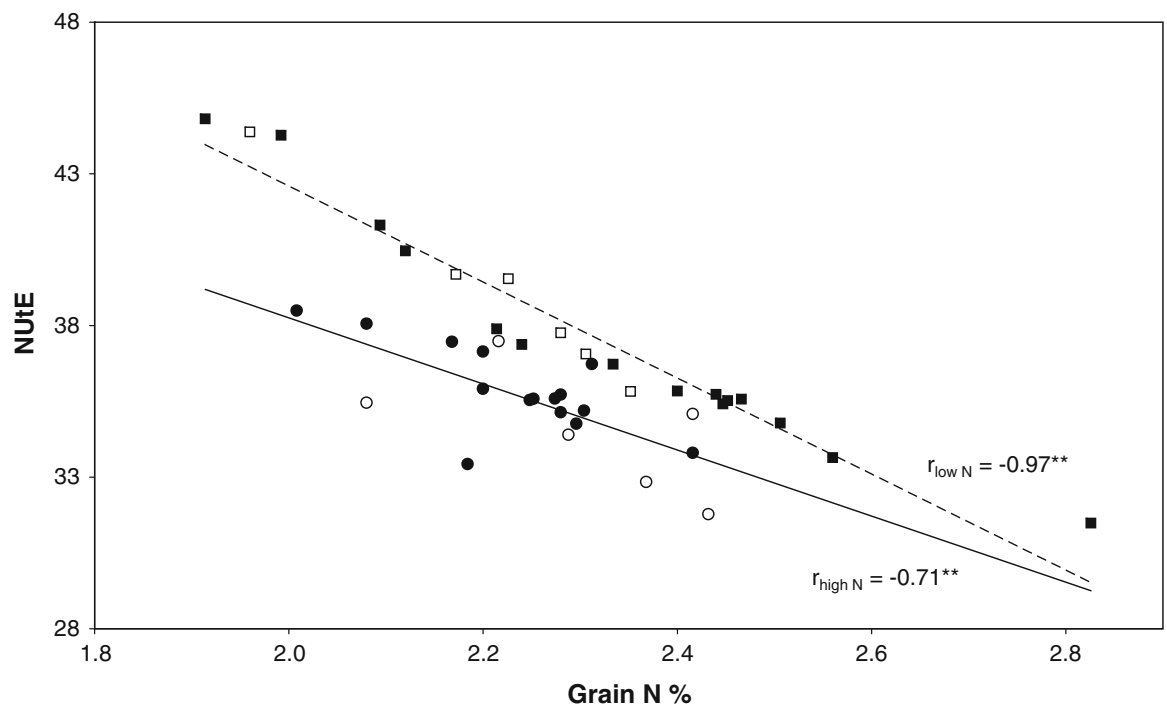

accumulated in grains $(\mathrm{Gw} / \mathrm{Ng})$, suggesting transgressive effects in the characteristics. In this field condition, Gw/Ng contributed mostly to NUtE $\left(\mathrm{R}^{2}\right.$ equals 0.50 and 0.94 under high and low $\mathrm{N}$, respectively). However, because $\mathrm{Gw} / \mathrm{Ng}$ is the inverse of grain $\mathrm{N}$ percentage, these efficient $\mathrm{F}_{2} \mathrm{~S}$ tended to form more grains with lower protein content (Fig. 1). On the other hand, $\mathrm{N}$ harvest index (NHI) was significantly associated with NUtE only under high $\mathrm{N}(r=0.70, P<0.01)$ and no such correlation occurred under low $\mathrm{N}$. In view of the dynamics and sink/source regulations of $\mathrm{N}$ distribution within the crop canopy (Simmonds 1995; Jamieson and Semenov 2000; Martre et al. 2003; Barneix 2007; Bertheloot et al. 2008), the negative relationship between grain $\mathrm{N}$ concentration and NUtE observed in this study appeared to have less connotations with variation in mechanisms of $\mathrm{N}$ deposition in grains, but more likely was related to differences in sink size resembling a $\mathrm{N}$ dilution effect. This implies that the proposal of Martre et al. (2007) to search for genotypes able to translocate larger amounts of $\mathrm{N}$ to grains without reducing plant biomass and photosynthetic capacity under $\mathrm{N}$ shortage has become particularly challenging for local breeders. Nevertheless, a further improvement of grain protein content under $\mathrm{N}$-limited conditions without substantial depressions in yielding capacity seems to be possible in bread wheat, as suggested by Laperche et al. (2007). In their recent study, at least some genome regions responsible for wheat performance and protein content (e.g. those from the $1 \mathrm{~B}$ and $2 \mathrm{~A}$ linkage groups) were not found to colocalise with other QTLs negatively influencing the yield-protein relationship.

In the present study, the plants abilities to take up $\mathrm{N}$ from the soil (NUpE), to translocate $\mathrm{N}$ into grains $(\mathrm{NHI}$, to produce grain dry matter per $\mathrm{N}$ unit accumulated in grains $(\mathrm{Gw} / \mathrm{Ng})$ and to utilize the absorbed $\mathrm{N}$ efficiently in grain mass formation (NUtE) were significantly affected by the soil treatments (Table 1). Except for $\mathrm{Gw} / \mathrm{Ng}$ in the field experiment, the physiological measures of $\mathrm{N}$ efficiency tended to increase under low N. Noteworthy, however, the magnitude of the $\mathrm{N}$-induced alterations in the majority of the efficiency components was distinctly dependent upon the genotype, as evident by the significant genotype $\times$ environment interactions. The result is consistent with observations previously reported in wheat (El Bassam 1998; Le Gouis et al. 2000, 2002), barley (Ceccarelli 1994, 1996; Górny and Sodkiewicz 2001) and maize (Di Fonzo et al. 1982; Medici et al. 2004; Presterl et al. 2008), corroborating that an evaluation of breeding materials under diverse fertilization regimes is necessary for choice of the most efficient parental forms and/or cross combinations, as suggested by others (Brancourt-Hulmel et al. 2005; Laperche et al. 2006a; Dawson et al. 2008; Wolfe et al. 2008).

The proportion of genotypic variance to total phenotypic variance, as measured by broad-sense heritabilities, was only moderate for most characters under study. The proportion usually did not exceed 
$60 \%$ demonstrating limited genetic variability and relatively strong environmental pressure on the expression of most $\mathrm{N}$ efficiency components. Only under more controlled conditions of the pot-experiment, the heritabilities of NUpE and NUtE reached $74-81 \%$ indicating a reduced influence of environmental forces on both traits.

\section{Combining ability effects}

Analysis of variance for general (GCA) and specific (SCA) combining abilities was performed separately for each treatment to identify possible influences of the environmental treatments on GCA and SCA effects. As demonstrated in Tables 2 and 3, contributions of the effects for the whole variance were strongly dependent upon the soil $\mathrm{N}$ status. In both experiments, GCA effects were the sole significant source of variance only in plants grown under high $\mathrm{N}$ conditions, except for NHI in pot-grown plants. In contrast, both GCA and SCA effects were significant

Table 2 Field experiment

\begin{tabular}{|c|c|c|c|c|c|}
\hline \multirow{2}{*}{$\begin{array}{l}\text { Trait }^{\mathrm{a}} \\
\text { d.f.: }\end{array}$} & \multicolumn{4}{|c|}{ Mean squares } & \multirow[t]{2}{*}{$\overline{\sigma_{\mathrm{A}}^{2} / \sigma_{\mathrm{D}}^{2}}$} \\
\hline & $\begin{array}{l}\text { Entries } \\
20\end{array}$ & $\begin{array}{l}\text { Gca } \\
5\end{array}$ & $\begin{array}{l}\text { Sca } \\
15\end{array}$ & $\begin{array}{l}\text { Error } \\
80\end{array}$ & \\
\hline \multicolumn{6}{|l|}{ NUpE } \\
\hline High N & 117 & $-{ }^{\mathrm{b}}$ & - & 122 & - \\
\hline Low N & $409 * *$ & $533 * *$ & $367 * *$ & 53 & 0.13 \\
\hline \multicolumn{6}{|l|}{ NHI } \\
\hline High N & $42.5^{* *}$ & $114.1 * *$ & 18.6 & 11.0 & 3.14 \\
\hline Low N & $7.9 * *$ & $10.7 * *$ & $7.0 * *$ & 2.8 & 0.22 \\
\hline \multicolumn{6}{|l|}{$\mathrm{Gw} / \mathrm{Ng}$} \\
\hline High N & $25.0 * *$ & $53.7 * *$ & 15.4 & 9.9 & 1.74 \\
\hline Low N & $85.3 * *$ & $163.3 * *$ & $59.3 * *$ & 4.9 & 0.48 \\
\hline \multicolumn{6}{|l|}{ NUtE } \\
\hline High N & $14.5^{* *}$ & $34.8 * *$ & 7.7 & 6.2 & 4.51 \\
\hline Low N & $64.1 * *$ & $143.2 * *$ & $37.7 * *$ & 2.9 & 0.76 \\
\hline
\end{tabular}

Analysis of variance (MS-values) and the ratio of additive/ dominance variances $\left(\sigma_{\mathrm{A}}^{2} / \sigma_{\mathrm{D}}^{2}\right)$ for $\mathrm{N}$ uptake efficiency and components of $\mathrm{N}$ utilization efficiency in a winter wheat diallel under high N (in Choryń 2005) and low N (in Poznań 2007) fertilization levels

a Trait abbreviations: $N U p E \mathrm{~N}$ uptake efficiency, $\mathrm{NHI}$ nitrogen harvest index, $G w / N g$ grain dry weight production per grain $\mathrm{N}$ unit, $N U t E \mathrm{~N}$ utilization efficiency ratio

b Not estimated due to a lack of genotypic variation

** Significant at $P=0.01$
Table 3 Pot experiment

\begin{tabular}{|c|c|c|c|c|c|}
\hline \multirow{2}{*}{$\begin{array}{l}\text { Trait }^{\mathrm{a}} \\
\text { d.f.: }\end{array}$} & \multicolumn{4}{|c|}{ Mean squares } & \multirow[t]{2}{*}{$\sigma_{\mathrm{A}}^{2} / \sigma_{\mathrm{D}}^{2}$} \\
\hline & $\begin{array}{l}\text { Entries } \\
20\end{array}$ & $\begin{array}{l}\text { Gca } \\
5\end{array}$ & $\begin{array}{l}\text { Sca } \\
15\end{array}$ & $\begin{array}{l}\text { Error } \\
60\end{array}$ & \\
\hline \multicolumn{6}{|l|}{ NUpE } \\
\hline High N & $188.4 * *$ & $661.6 * *$ & 30.7 & 28.6 & 75.15 \\
\hline Low N & $92.2 * *$ & $274.6 * *$ & 31.5 & 21.7 & 6.48 \\
\hline \multicolumn{6}{|l|}{ NHI } \\
\hline High N & $38.1 * *$ & $111.3 * *$ & $13.7 * *$ & 4.4 & 2.67 \\
\hline Low $\mathrm{N}$ & $13.9 * *$ & $20.9 * *$ & $11.5^{*}$ & 5.2 & 0.37 \\
\hline \multicolumn{6}{|l|}{$\mathrm{Gw} / \mathrm{Ng}$} \\
\hline High N & $10.8 *$ & $19.0^{*}$ & 8.1 & 5.7 & 1.13 \\
\hline Low $\mathrm{N}$ & $10.0 * *$ & $17.0 * *$ & $7.7 * *$ & 2.6 & 0.45 \\
\hline \multicolumn{6}{|l|}{ NUtE } \\
\hline High N & $9.9 * *$ & $30.4 * *$ & 3.1 & 2.3 & 8.53 \\
\hline Low N & $6.9 * *$ & $13.9 * *$ & $4.5^{* *}$ & 1.8 & 0.86 \\
\hline
\end{tabular}

Analysis of variance (MS-values) and the ratio of additive/ dominance variances $\left(\sigma_{\mathrm{A}}^{2} / \sigma_{\mathrm{D}}^{2}\right)$ for $\mathrm{N}$ uptake efficiency and components of $\mathrm{N}$ utilization efficiency in a winter wheat diallel under varied $\mathrm{N}$ fertilization

a Trait abbreviations: $N U p E \mathrm{~N}$ uptake efficiency, $\mathrm{NHI}$ nitrogen harvest index, $G w / N g$ grain dry weight production per grain $\mathrm{N}$ unit, $N U t E \mathrm{~N}$ utilization efficiency ratio

*,** Significant at $P=0.05$ and $P=0.01$, respectively

for all traits under reduced $\mathrm{N}$ nutrition, except for NUpE in pots. The distinct preponderance of additive over dominance variance, as indicated by the increased $\left(\sigma_{\mathrm{A}}^{2} / \sigma_{\mathrm{D}}^{2}\right)$-ratios found under high $\mathrm{N}$ conditions, considerably diminished under $\mathrm{N}$ shortage where $\sigma_{\mathrm{D}}^{2}$ appeared to have a critical role.

These observations are in partial conflict with data reported by Le Gouis et al. (2002) who in N-limited diallel $F_{1}$ hybrids between modern French cultivars found markedly higher GCA/SCA ratios for grain yield, grain $\mathrm{N}$ yield and total above-ground $\mathrm{N}$ than in those grown under high $\mathrm{N}$ nutrition. More recently, a similar preponderance of GCA effects for $\mathrm{N}$ uptake and NUtE was identified in $\mathrm{F}_{2}$ and $\mathrm{F}_{3}$ progenies of factorial hybrids between modern and exotic cultivars of barley grown under reduced $\mathrm{N}$ fertilization (Górny and Ratajczak 2008). On the other hand, results of the present study on wheat appear to be in accord with similar $\mathrm{N}$ shortage-induced increases in the importance of non-additive effects for grain yield and components of NUE previously reported in maize ( $\mathrm{Di}$ Fonzo et al. 1982; Medici et al. 2004) and those for NUtE in barley (Górny and Sodkiewicz 2001). 
Table 4 GCA effects for $\mathrm{N}$ uptake efficiency (NUpE) and $\mathrm{N}$ utilization efficiency ratio (NUtE) in the field- and pot-grown winter wheats under varied $\mathrm{N}$ fertilization

\begin{tabular}{|c|c|c|c|c|c|c|c|c|}
\hline \multirow[t]{3}{*}{ Parent } & \multicolumn{4}{|l|}{ NUpE } & \multicolumn{4}{|l|}{ NUtE } \\
\hline & \multicolumn{2}{|l|}{ Field } & \multicolumn{2}{|l|}{ Pots } & \multicolumn{2}{|l|}{ Field } & \multicolumn{2}{|l|}{ Pots } \\
\hline & High N & Low N & High N & Low $\mathrm{N}$ & High N & Low $\mathrm{N}$ & High N & Low $\mathrm{N}$ \\
\hline Mironovska & $-3.41 *$ & $4.47 * *$ & $7.73 * *$ & $5.11 * *$ & $-1.53 * *$ & $-2.44 * *$ & $0.84 * *$ & $0.64 * *$ \\
\hline M. Huntsman & -1.05 & -1.36 & $1.77 *$ & 0.80 & 0.36 & $0.56^{*}$ & -0.37 & $0.49 *$ \\
\hline Clever & $4.30 * *$ & $-5.43 * *$ & $-5.03 * *$ & -1.36 & $0.78 *$ & $2.59 * *$ & $0.79 * *$ & 0.00 \\
\hline Kris & -1.04 & $-2.11 *$ & $-3.69 * *$ & -1.35 & $1.00 * *$ & $1.55^{* *}$ & $0.77 * *$ & 0.28 \\
\hline Finezja & 1.09 & $2.94 * *$ & -1.17 & 0.31 & -0.55 & $-1.08 * *$ & -0.44 & -0.23 \\
\hline Korweta & 0.11 & 1.49 & 0.38 & $-3.51 * *$ & -0.06 & $-1.18 * *$ & $-1.58 * *$ & $-1.18 * *$ \\
\hline
\end{tabular}

*,** Significant at $P=0.05$ and $P=0.01$, respectively

Nevertheless, these observations may have important implications for domestic wheat breeding practices; namely, the easier strategy to improve wheat $\mathrm{N}$ efficiency using selection for GCA effects may be a less adequate method with the realization that SCAs could even predominate in early cross generations of some wheat collections when these are grown under low $\mathrm{N}$ conditions.

Parental GCA effects for NUpE and NUtE in both experiments are given in Table 4. There was a weak consistency of GCAs under different conditions. The largest positive GCA effects for NUpE were usually exhibited by cv. Mironovska, but not in the highly $\mathrm{N}$-fertilized field. In turn, Clever showed negative GCAs for NUpE in pots and in the field under low $\mathrm{N}$, but contributed towards increased $\mathrm{NUpE}$ in the field under high $\mathrm{N}$ conditions. The GCA effects for NUtE were more stable. The British cvs. Clever and Kris had usually the largest positive GCAs, whereas the Polish cv. Korweta tended to contribute most negatively for NUtE in its progenies. The GCA effects of Mironovska exhibited distinct interactions with experimental conditions; its hybrid progenies utilized $\mathrm{N}$ with a high efficiency only in pots, but not under field conditions.

As mentioned above, the specific combining abilities were significant mainly in plants grown under nitrogen shortage. Table 5 presents SCA effects for NUpE and NUtE under low $\mathrm{N}$ conditions. If significant, they were more frequently identified in the field than in pot-grown plants. Interestingly, a negative relationship between the SCAs for NUpE and NUtE was observed, and hybrids with the highest SCAs for NUpE exhibited the lowest SCAs for NUtE. This
Table 5 SCA effects for $\mathrm{N}$ uptake efficiency (NUpE) and $\mathrm{N}$ utilization efficiency ratio (NUtE) in the field- and pot-grown hybrid progenies of winter wheat under low $\mathrm{N}$ fertilization. Parental abbreviations: Mironovska (Mi), Maris Huntsman (Mh), Clever (Cl), Kris (Kr), Finezja (Fi), Korweta (Ko)

\begin{tabular}{|c|c|c|c|c|}
\hline \multirow[t]{2}{*}{$\mathrm{F}_{2}$ hybrid } & \multicolumn{2}{|c|}{ NUpE at low $\mathrm{N}$} & \multicolumn{2}{|c|}{ NUtE at low $\mathrm{N}$} \\
\hline & Field & Pots & Field & Pots \\
\hline $\mathrm{Mi} \times \mathrm{Mh}$ & 4.90 & -1.25 & -0.14 & 1.09 \\
\hline $\mathrm{Mi} \times \mathrm{Cl}$ & 0.50 & -1.61 & -0.64 & 1.12 \\
\hline $\mathrm{Mi} \times \mathrm{Kr}$ & 5.68 & 1.76 & $-1.40 *$ & -0.98 \\
\hline $\mathrm{Mi} \times \mathrm{Fi}$ & 1.74 & -0.75 & 0.71 & 0.64 \\
\hline $\mathrm{Mi} \times \mathrm{Ko}$ & $11.67 * *$ & $5.73 *$ & $-2.77 * *$ & 0.08 \\
\hline $\mathrm{Mh} \times \mathrm{Cl}$ & -4.37 & -1.71 & $3.80 * *$ & 1.14 \\
\hline $\mathrm{Mh} \times \mathrm{Kr}$ & $-6.10^{*}$ & -0.31 & $1.34^{*}$ & 0.57 \\
\hline $\mathrm{Mh} \times \mathrm{Fi}$ & $5.88 *$ & $4.89 *$ & $-1.82 * *$ & -0.59 \\
\hline $\mathrm{Mh} \times \mathrm{Ko}$ & -2.27 & -3.21 & 0.65 & $1.63 * *$ \\
\hline $\mathrm{Cl} \times \mathrm{Kr}$ & -5.03 & 1.09 & $2.28 * *$ & 0.20 \\
\hline $\mathrm{Cl} \times \mathrm{Fi}$ & $13.02 * *$ & $-6.07 * *$ & $-4.04 * *$ & -1.15 \\
\hline $\mathrm{Cl} \times \mathrm{Ko}$ & $9.68 * *$ & 0.03 & $-4.48 * *$ & -0.85 \\
\hline $\mathrm{Kr} \times \mathrm{Fi}$ & $6.24 *$ & -0.39 & $-1.62 *$ & 1.07 \\
\hline $\mathrm{Kr} \times \mathrm{Ko}$ & -3.23 & -0.54 & $2.23 * *$ & 0.19 \\
\hline $\mathrm{Fi} \times \mathrm{Ko}$ & 1.25 & 0.86 & -0.35 & -0.05 \\
\hline$r^{\mathrm{a}}$ & 0.14 & & $0.60 *$ & \\
\hline
\end{tabular}

$\overline{{ }^{a} \text { Coefficient of correlation between the field and pot indices }}$ *,** Significant at $P=0.05$ and $P=0.01$, respectively

relationship was particularly evident in the field experiment under low $\mathrm{N}$ at Poznań $(r=-0.92$, $P<0.01)$ indicating that, at least in the examined wheat assortment, a reduced uptake capacity of an entry was usually connected with its more efficient utilization when absorbed, and vice versa. 
High-yielding crops from intensive ecosystems tend to be less efficient in the nutrient uptake and an improved crop adaptation to conditions of reduced $\mathrm{N}$-input is frequently reported to be mainly associated with enhanced NUpE (Gastal and Lemaire 2002; Dawson et al. 2008; Presterl et al. 2008). It is well known that at least some important genes responsible for $\mathrm{N}$ uptake (e.g. the HATs system) are up-regulated by $\mathrm{N}$ shortage in the soil or feedback-regulation depending upon the shoots' demand for $\mathrm{N}$ (Wirén et al. 1997; Forde 2002). Moreover, both processes$\mathrm{N}$ uptake and $\mathrm{N}$ utilization-appear to be governed by different genetic factors (Hirel et al. 2001; Gallais and Hirel 2004; Good et al. 2004). For instance, results of extensive molecular studies on wheat and maize (Bertin and Gallais 2000, 2001; Quarrie et al. 2005; Habash et al. 2007; Laperche et al. 2007) revealed that different sets of genes (QTL regions) controlled various components of the two major measures of $\mathrm{N}$ efficiency, and that expression of the genes (loci) was considerably dependent upon soil $\mathrm{N}$ status. Hence, the appearance of the above-mentioned negative relationship between NUpE and NUtE in the examined hybrids and their parents may be a genetic quandary. We can hypothesize that the breeding history and specific selection forces during the development of parents may considerably contribute to this variation and co-variation. Only cvs. Mironovska 808 and M. Huntsman were likely bred under less intensive fertilization levels of the 1960's, whereas the remaining modern parents were developed under enhanced $\mathrm{N}$ fertilization with strong selection for yielding capacity and grain quality. Thus, such a strategy may have favoured highyielding genotypes with increased NUtE, but not those with a high NupE.

Except for SCAs for NUtE under low N conditions, there were no close relationships between the field and pots estimates of general and specific combining abilities. This lack of consistency was primarily associated with the interacting GCAs of Mironovska and Clever, and the analogous SCA effect of Clever $\times$ Finezja (Tables 4 and 5). Since this discrepancy mainly concerns the efficiency in $\mathrm{N}$ uptake, it could be due to genetic effects, but is more likely due to effects of the microenvironment in the pot experimentation, especially with regard to restricted rooting capacity. Hence, a strong caution is needed when extrapolating such pot trial data to field conditions, particularly when genotypes with distinct differences in root morphology are being investigated.

\section{Genetic components of variation}

The genetic components of variation in both experiments confirm the crucial influence of soil treatments used on gene action governing $\mathrm{N}$ efficiency. In the field experiment, the estimates of Mather's genetic components revealed that $D$, which measures additive gene action, was almost exclusively significant for the characters only under high $\mathrm{N}$ fertilization applied in Choryń 2005 (Table 6). However, the role of dominance distinctly increased under the low $\mathrm{N}$ supply in Poznań 2007 as shown by the highly significant $H 1$ and $H 2$ parameters. $F$ was not significantly different from zero, thus it may be assumed that dominant and recessive alleles were present in equal proportions in the parents. The equality of the estimates of $\mathrm{H} 1$ and $\mathrm{H} 2$ found under low $\mathrm{N}$ indicates that the positive and negative alleles at all loci exhibiting dominance were in equal frequencies. The mean degrees of dominance, as measured by $(1 / 4 H 1 / D)^{1 / 2}$, were relatively low under high $\mathrm{N}$ fertilization indicating partial dominance for all characters in these conditions. Under $\mathrm{N}$ shortage, however, the dominance effects critically increased to the overdominance range for $\mathrm{NUpE}$ and $\mathrm{Gw} / \mathrm{Ng}$ and complete dominance for NUtE. Furthermore, the sum of dominance effects over all heterozygous loci $(h 2)$ was significant for most characters, independently on $\mathrm{N}$ treatment. Except for NHI under high N, narrowsense heritabilities for the components of $\mathrm{N}$ efficiency were low ranging from 0.18 for $\mathrm{NUpE}$ to 0.44 for NUtE.

In the greenhouse experiment, there was a marked preponderance of additive variance, especially under high $\mathrm{N}$ nutrition (Table 7). In accordance with results of the ANOVA for combining ability (Table 3), additive gene action ( $D$-values) was solely responsible for variation in most characters under high $\mathrm{N}$, except NHI for which both the additive and dominance components were significant, independently of soil $\mathrm{N}$ status. Similar to the field experiment, the importance of dominance components $(H 1$ and $H 2$ ) critically increased under low $\mathrm{N}$, except $\mathrm{NUpE}$ that was governed exclusively by additive gene action under both nutrition regimes. In non-stressed plants, the average degree of dominance ranged from 0.13 for 
Table 6 Field experiment

\begin{tabular}{|c|c|c|c|c|c|c|c|}
\hline \multirow[t]{2}{*}{ Trait $^{\mathrm{a}}$} & \multicolumn{5}{|c|}{ Genetic parameter } & \multirow[t]{2}{*}{$(1 / 4 H 1 / D)^{1 / 2}$} & \multirow[t]{2}{*}{$\overline{h_{\mathrm{NS}}^{2}}$} \\
\hline & $D$ & $F$ & $H 1$ & $H 2$ & $h 2$ & & \\
\hline \multicolumn{8}{|l|}{ NUpE } \\
\hline High N & $-{ }^{\mathrm{b}}$ & - & - & - & - & - & - \\
\hline Low N & $20.4^{*}$ & 14.7 & $203.8 * *$ & $149.3 * *$ & $236.6 * *$ & 1.58 & 0.18 \\
\hline \multicolumn{8}{|l|}{ NHI } \\
\hline High $N$ & $11.35 * *$ & 3.53 & 4.91 & 5.09 & 1.92 & 0.33 & 0.58 \\
\hline Low N & $1.15^{*}$ & 0.61 & $2.76^{*}$ & $2.82 * *$ & 0.18 & 0.78 & 0.30 \\
\hline \multicolumn{8}{|l|}{$\mathrm{Gw} / \mathrm{Ng}$} \\
\hline High N & $4.10^{*}$ & 0.24 & 2.94 & 3.41 & $4.77 *$ & 0.42 & 0.32 \\
\hline Low N & $6.84 * *$ & 0.48 & $40.69 * *$ & $28.77 * *$ & $11.29 * *$ & 1.22 & 0.33 \\
\hline \multicolumn{8}{|l|}{ NUtE } \\
\hline High $\mathrm{N}$ & $2.35^{*}$ & -0.20 & 0.26 & 0.46 & $5.43 * *$ & 0.17 & 0.31 \\
\hline Low N & $7.04 * *$ & -0.29 & $26.12 * *$ & $18.24 * *$ & $7.53 * *$ & 0.96 & 0.44 \\
\hline
\end{tabular}

Mather's genetic parameters $(D, F, H 1, H 2, h 2)$, average degree of dominance $\left[(1 / 4 H 1 / D)^{1 / 2}\right]$ and narrow-sense heritabilities $\left(\mathrm{h}_{\mathrm{NS}}^{2}\right)$ for $\mathrm{N}$ uptake efficiency and components of $\mathrm{N}$ utilization efficiency in $\mathrm{F}_{2}$ populations of a winter wheat diallel grown under high (in Choryń 2005) and low (in Poznań 2007) N fertilization levels

a Trait abbreviations: $N U p E \mathrm{~N}$ uptake efficiency, $\mathrm{NHI}$ nitrogen harvest index, $\mathrm{Gw} / \mathrm{Ng}$ grain dry weight production per grain $\mathrm{N}$ unit, $N U t E \mathrm{~N}$ utilization efficiency ratio

b Not estimated due to lack of genotypic variation

*,** Significant at $P=0.05$ and $P=0.01$, respectively

Table 7 Pot experiment

\begin{tabular}{|c|c|c|c|c|c|c|c|}
\hline \multirow[t]{2}{*}{ Trait $^{\mathrm{a}}$} & \multicolumn{5}{|c|}{ Genetic parameter } & \multirow[t]{2}{*}{$(1 / 4 H 1 / D)^{1 / 2}$} & \multirow[t]{2}{*}{$\overline{h_{\mathrm{NS}}^{2}}$} \\
\hline & $D$ & $F$ & $H 1$ & $H 2$ & $h 2$ & & \\
\hline \multicolumn{8}{|l|}{ NUpE } \\
\hline High N & $54.35 * *$ & -13.82 & 3.48 & 1.31 & 0.20 & 0.13 & 0.58 \\
\hline Low N & $21.98 * *$ & -6.94 & 7.78 & 9.28 & 0.57 & 0.30 & 0.41 \\
\hline \multicolumn{8}{|l|}{ NHI } \\
\hline High $N$ & $16.64 * *$ & $8.10 * *$ & $8.05^{*}$ & $7.06^{*}$ & 1.96 & 0.35 & 0.87 \\
\hline Low N & $2.10 *$ & 0.56 & $5.26^{*}$ & $5.33^{*}$ & 0.75 & 0.79 & 0.25 \\
\hline \multicolumn{8}{|l|}{$\mathrm{Gw} / \mathrm{Ng}$} \\
\hline High $N$ & $2.35 *$ & 1.49 & 2.22 & 1.95 & 0.39 & 0.49 & 0.30 \\
\hline Low N & $0.90 *$ & -0.30 & $3.85^{*}$ & $3.17 *$ & $5.85^{* *}$ & 1.03 & 0.19 \\
\hline \multicolumn{8}{|l|}{ NUtE } \\
\hline High N & $3.65 * *$ & $1.28 * *$ & 0.77 & 0.35 & $1.15^{* *}$ & 0.23 & 0.66 \\
\hline Low N & $0.92 * *$ & -0.17 & $2.14 * *$ & $1.75 * *$ & $2.56 * *$ & 0.76 & 0.28 \\
\hline
\end{tabular}

Mather's genetic parameters $(D, F, H 1, H 2, h 2)$, average degree of dominance $\left[(1 / 4 H 1 / D)^{1 / 2}\right]$ and narrow-sense heritabilities $\left(\mathrm{h}_{\mathrm{NS}}^{2}\right)$ for $\mathrm{N}$ uptake efficiency and components of $\mathrm{N}$ utilization efficiency in $\mathrm{F}_{2}$ populations of a winter wheat diallel grown under variable $\mathrm{N}$ fertilization

a Trait abbreviations: NUpE, $\mathrm{N}$ uptake efficiency, NHI, nitrogen harvest index; Gw/ $\mathrm{Ng}$, grain dry weight production per grain $\mathrm{N}$ unit; NUtE, $\mathrm{N}$ utilization efficiency ratio

*,** Significant at $P=0.05$ and $P=0.01$, respectively 
$\mathrm{NUpE}$ to 0.49 for $\mathrm{Gw} / \mathrm{Ng}$ indicating very low or incomplete dominance. Under $\mathrm{N}$ shortage, the importance of dominance effects considerably enhanced attaining complete dominance for $\mathrm{Gw} / \mathrm{Ng}$. Narrowsense heritabilities for the efficiency components in plants supplied with high $\mathrm{N}(0.30-0.87)$ were distinctly higher than those in N-limited plants (0.19-0.41).

From these results it is apparent that the stressinduced enhancement in the contribution of dominance and likely epistatic interactions of genes for variation in $\mathrm{N}$ efficiency may impede efforts to breed physiologically efficient winter wheats better adapted to agriculture under reduced $\mathrm{N}$ input. Thus, selection procedures that will eliminate the masking nonadditive effects under limited fertilization levels are necessary to overcome the barriers.

Classifying the parents and hybrids

The ability of plants to respond to each additional amount of added and absorbed nitrogen with an increased efficiency of utilization in grain mass formation may be considered an important component of plant adaptation to gradients of nutrient supply. Thus, an attempt was made to categorize the examined entries for yield potential under low $\mathrm{N}$ conditions and fertilization- induced alterations in physiological ability to utilize absorbed $\mathrm{N}$ efficiently. The relative distributions of the parents and hybrid progenies in this classification are shown in Fig. 2a. Using data from the field experiment, the entries were classified into the following groups:

(1) “efficient and responsive", i.e. entries yielding more grain than average under low $\mathrm{N}$ and exhibiting the greatest ability to utilize additional $\mathrm{N}$ with an enhanced efficiency; these entries can produce well under low $\mathrm{N}$ fertilization and are able to respond well with enhanced $\mathrm{N}$ availability. This group mainly included hybrid progenies of the old cv. Mironovska 808 and the modern British cv. Clever crossed with the Polish cvs. Finezja and Korweta;

(2) "efficient and non-responsive", i.e. well-yielding entries with limited physiological ability to utilize additional $\mathrm{N}$ efficiently; this group included the parental $\mathrm{cv}$. Kris and three hybrids (Mironovska $\times$ M. Huntsman, M. Huntsman $\times$ Clever and Kris $\times$ Korweta);
(3) "non-efficient and non-responsive", and

(4) "non-efficient and responsive", i.e. genotypes with a limited yield potential under low $\mathrm{N}$ and (mostly) a reduced ability to utilize additional $\mathrm{N}$ efficiently; these groups included all remaining parents and hybrids.

According to Fageria and Baligar (1993, 1997), progenies belonging to the 1st group (above all) and 2nd group (to a lesser extent) appear to be the most desirable materials for breeding programs that deal with adaptation to low-input agriculture. However, even though this categorization of the parents and hybrids did provide useful information, the data obtained may be questioned to some extent. Namely, this grouping does not provide clear information either on differences in yield potential in highly fertilized fields or on genotypic variation in the magnitude of $\mathrm{N}$ shortage-induced depressions in grain yield. Therefore, an attempt was also made to discriminate the entries for the yield-indicated tolerance to low $\mathrm{N}$ fertilization (Fig. 2b). A careful inspection of data in both figures provides a more detailed insight into all major interactions.

When the entries were classified according to NUtE-response index and tolerance level (Fig. 2b), it was apparent that the 'efficient and responsive' progenies of cv. Clever were sensitive to $\mathrm{N}$ shortage. In turn, among the four most responding and tolerant hybrids, three of them were cv. Mironovska hybrids, viz. Mironovska $\times$ Kris, Mironovska $\times$ Finezja and Mironovska $\times$ Korweta. Likewise, cv. Mironovska and its two remaining hybrids were also tolerant to low N. It is interesting that almost all hybrids of $\mathrm{cv}$. Mironovska produced more than average grain yields under low $\mathrm{N}$ conditions. However, this was accompanied by their decreased yields under high $\mathrm{N}$ conditions suggesting that the low-yielding cv. Mironovska contributed mainly towards an increased NUtEresponse index and enhanced tolerance, i.e. a more stable yielding capacity. This was not surprising because cv. Mironovska was from the 1970's frequently used by domestic wheat breeders as a source of yield stability, winterhardiness, quality and rooting capacity, and numerous Polish cultivars have this source in their ancestry. The biplots also show that the British cvs. M. Huntsman and Kris contribute towards increased NUtE-response index and enhanced tolerance to low $\mathrm{N}$, especially when crossed with 
Fig. 2 Categorization of parents and their hybrid progenies for the yieldindicated efficiency under reduced $\mathrm{N}$ fertilization $\left(\mathrm{kg} \mathrm{m}^{-2}\right)$ and NUtEresponse index $\left(\mathrm{g} \mathrm{g}^{-1}\right)$, i.e. a physiological ability to utilize each additional unit of absorbed $\mathrm{N}$ with an increased efficiency (a) and for the yield-indicated tolerance to low $\mathrm{N}$ and NUtE-response index (b). The entries are grouped depending upon the overall means indicated by vertical and horizontal solid lines. $\mathrm{LSD}_{0.05}$ for $\mathrm{GY}=0.036$. Parental abbreviations: Mironovska (Mi), Maris Huntsman (Mh), Clever $(\mathrm{Cl})$, Kris (Kr), Finezja (Fi), Korweta (Ko). The $\mathrm{F}_{2}$ hybrids are abbreviated in the following manner: e.g. Mironovska/Kris, Mi.Kr
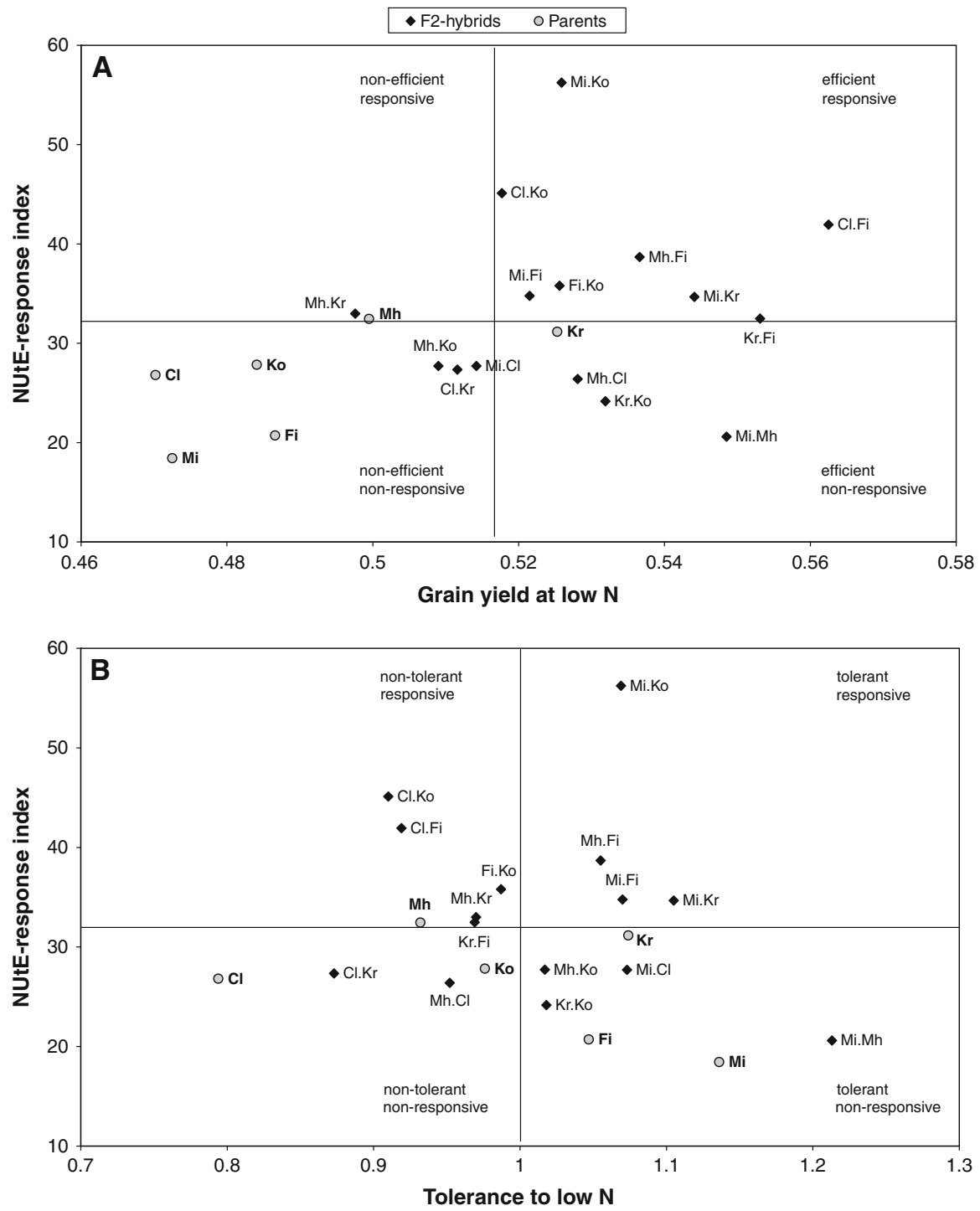

cv. Finezja. The lowest stress-induced depression in grain yield occurred in Mironovska $\times$ M. Huntsman. This may at least partly be associated with the excellent rooting capacities of both parents, especially that of M. Huntsman (Górny and Patyna 1992; Górny et al. 2006b). It is noteworthy that progenies of both parental cultivars tended to produce relatively high grain yields under low $\mathrm{N}$ conditions, but usually gave lower yields with high $\mathrm{N}$ nutrition, confirming that in this investigation the highest yielding entries tended to be less tolerant to $\mathrm{N}$ shortage, as demonstrated in Fig. 3. These observations imply that selection for high yield in favourable environments might lead to identification of wheat genotypes with greater stress- induced yield depressions, i.e. forms less adapted to low-input agriculture.

\section{Conclusions}

Although the parents and hybrids of winter wheat exhibited considerable differences in major components of $\mathrm{N}$ efficiency, the range of the exploitable additive variance appears to be narrow. Hence, for progress to be achieved, it may be necessary to broaden and diversify the current gene pool used by wheat breeders. Nevertheless, there are old and modern wheats that could serve as adequate initial 
Fig. 3 Relationship between grain yield under high $\mathrm{N}$ fertilization and level of tolerance to low $\mathrm{N}$ in parents and $\mathrm{F}_{2}$ hybrids. Entries are abbreviated as in Fig. 1



donors of various efficiency components. Identifying efficiency genes in various genotypes and pyramiding them in segregating populations will be a crucial objective. The evidence that $\mathrm{N}$ utilization efficiency is negatively associated with both $\mathrm{N}$ uptake efficiency and grain $\mathrm{N}$ concentration in the materials examined implies that a search in the national wheat germplasm for genotypes more efficient in $\mathrm{N}$ uptake and able to translocate larger amounts of $\mathrm{N}$ to grains without reducing grain yield under $\mathrm{N}$ shortage has become particularly challenging for local breeders. Considering the inheritance modes revealed among $F_{2}$ populations and environmental effects on the expression of components of $\mathrm{N}$ efficiency, these breeding objectives might be difficult to realize.

Results of the study provide a distinct indication that $\mathrm{N}$ fertilization levels have a critical influence on the expression of gene actions governing $\mathrm{N}$ efficiency in wheat. The effects of genotype $\times$ environment interaction for major components of the efficiency are quite large suggesting that a genotype most efficient in $\mathrm{N}$ uptake and $\mathrm{N}$ utilization in optimal conditions is not necessarily the most efficient under limited N. In favourable conditions only, components of $\mathrm{N}$ efficiency in winter wheat appear to be inherited in a manner being favourable for selection (preponderance of additive gene effects). Although it is difficult to generalize for all European wheat germplasm, the increased importance of non-additive genetic effects under nitrogen-limited conditions indicates that progress in breeding more efficient wheats better adapted to less-favourable $\mathrm{N}$ fertilization regimes may be slow. However, the dominance genetic variance, although large and significant for $\mathrm{NUpE}$ and $\mathrm{NUtE}$ in $\mathrm{F}_{2} \mathrm{~S}$ under $\mathrm{N}$-limited conditions, should decline in later generations with reductions in heterozygosity. Hence, selection in later generations may be necessary to fix the additive and additive $x$ additive effects and to overcome the masking non-additive causes. To prevail over the barriers, selection among both SSD-derived lines and/or dihaploid wheat populations would be the alternative strategy.

Acknowledgements The study was supported by the Ministry of Science and Higher Education (State Comm. Sci. Res.), Warsaw (no. 3PO6A 03724). The skilled technical assistance of MSc. Joanna Flisykowska and Lucyna Łagodzińska is greatly appreciated. We also thank the anonymous reviewers for valuable suggestions and comments on the manuscript.

Open Access This article is distributed under the terms of the Creative Commons Attribution Noncommercial License which permits any noncommercial use, distribution, and reproduction in any medium, provided the original author(s) and source are credited.

\section{References}

An D-G, Su J-Y, Liu Q-Y, Zhu J-G, Tong Y-P, Li J-M, Jing R-L, Li B, Li Z-S (2006) Mapping QTLs for nitrogen uptake in relation to the early growth of wheat (Triticum aestivum L.). Plant Soil 284:73-84

Baresel JP, Zimmermann G, Reents HJ (2008) Effects of genotype and environment on $\mathrm{N}$ uptake and $\mathrm{N}$ partition in 
organically grown winter wheat (Triticum aestivum L.) in Germany. Euphytica 163:347-354

Barneix AJ (2007) Physiology and biochemistry of sourceregulated protein accumulation in the wheat grain. J Plant Physiol 164:581-590

Barraclough PB, Howarth JR, Jones J, Lopez-Bellido R, Parmar S, Shepherd CE, Hawkesford MJ (2010) Nitrogen efficiency of wheat: genotypic and environmental variation and prospects for improvement. Eur J Agron 33:1-11

Bertheloot J, Martre P, Andrieu B (2008) Dynamics of light and nitrogen distribution during grain filling within wheat canopy. Plant Physiol 148:1707-1720

Bertin P, Gallais A (2000) Genetic variation for nitrogen use efficiency in a set of recombinant maize inbred lines. I. Agro-physiological results. Maydica 45:53-66

Bertin P, Gallais A (2001) Physiological and genetic basis of nitrogen use efficiency in maize. II. QTL detection and coincidences. Maydica 46:53-68

Brancourt-Hulmel M, Heumez E, Pluchard P, Beghin D, Depatureaux C, Giraud A, Le Gouis J (2005) Indirect versus direct selection of winter wheat for low-input or high-input levels. Crop Sci 45:1427-1431

Ceccarelli S (1994) Specific adaptation and breeding for marginal conditions. Euphytica 77:205-219

Ceccarelli S (1996) Adaptation to low/high input cultivation. Euphytica 92:203-214

Charmet G, Robert N, Branlard G, Linossier L, Martre P, Triboï E (2005) Genetic analysis of dry matter and nitrogen accumulation and protein composition in wheat kernels. Theor Appl Genet 111:540-550

Coque M, Gallais A (2007) Genetic variation for nitrogen remobilisation and post-silking nitrogen uptake in maize recombinant inbred lines: heritabilities and correlations among traits. Crop Sci 47:1787-1796

Dawson JC, Huggins DR, Jones SS (2008) Characterizing nitrogen use efficiency in natural and agricultural ecosystems to improve the performance of cereal crops in low-input and organic agricultural systems. Field Crop Res 107:89-101

Dhugga KS, Waines JG (1989) Analysis of nitrogen accumulation and use in bread and durum wheat. Crop Sci 29:1232-1239

Di Fonzo N, Motto M, Maggiore T, Sabatino R, Salamini F (1982) N-uptake, translocation and relationships among $\mathrm{N}$-related traits in maize as affected by genotype. Agronomie 2:789-796

Duncan RR, Baligar VC (1990) Genetics, breeding and physiological mechanisms of nutrient uptake and use efficiency: an overview. In: Baligar VC, Duncan RR (eds) Crops as enhancers of nutrient use. Academic Press Inc, San Diego, USA, pp 3-35

El Bassam N (1998) A concept of selection for 'low-input' wheat varieties. Euphytica 100:95-100

Fageria NK, Baligar VC (1993) Screening crop genotypes for mineral stresses. In: Duncan RR, Baligar VC (eds) Proceedings of the workshop on adaptation of plants to soil stresses. INTSORMIL Publ No 94-2, University of Nebraska, Lincoln, pp 142-159

Fageria NK, Baligar VC (1997) Upland rice genotypes evaluation for phosphorus use efficiency. J Plant Nutr 20:499-509
Fageria NK, Baligar VC (2005) Enhancing nitrogen use efficiency in crop plants. Adv Agron 88:97-185

Fischer RA, Maurer R (1978) Drought resistance in spring wheat cultivars. I. Grain yield responses. Aust J Agric Res 14:897-912

Fontaine JX, Ravel C, Pageau K, Heumez E, Dubois F, Hirel B, Le Gouis J (2009) A quantitative genetic study for elucidating the contribution of glutamine synthetase, glutamate dehydrogenase and other nitrogen-related physiological traits to the agronomic performance of common wheat. Theor Appl Genet 119:645-662

Forde BG (2002) The role of long-distance signalling in plant responses to nitrate and other nutrients. J Exp Bot 53:39-43

Gallais A, Hirel B (2004) An approach to the genetics of nitrogen use efficiency in maize. J Exp Bot 55:295-306

Gamzikova OI (1992) Genetic aspects in edaphical adaptation of wheat (in Russian). Fizjologia Biohimija Kulturnyh Rastienij 24:419-428

Gastal F, Lemaire G (2002) N uptake and distribution in crops: an agronomical and ecophysiological perspective. J Exp Bot 53:789-799

Good AG, Shrawat AK, Muench DG (2004) Can less yield more? Is reducing nutrient input into the environment compatible with maintaining crop production? Trends Plant Sci 9:597-605

Górny AG (1999) Inheritance of water use efficiency in diallel hybrids of spring barley under varied nutrition and soil moisture. J Appl Genet 40:15-28

Górny AG, Garczyński S (2002) Genotypic and nutritiondependent variation in water use efficiency and photosynthetic activity of leaves in winter wheat (Triticum aestivum L.). J Appl Genet 43:145-160

Górny AG, Patyna H (1992) The root system of wheat in the genetic and breeding researches. In: Czembor HJ (ed) Cereal breeding. I. Wheat breeding, Z. Probl. IHAR, Radzików 1992, 41-53 (in Polish)

Górny AG, Ratajczak D (2008) Efficiency of nitrogen and phosphorus utilization in progenies of factorial crosses between European and exotic cultivars of spring barley. J Appl Genet 49:349-355

Górny AD, Sodkiewicz T (2001) Genetic analysis of the nitrogen and phosphorus utilization efficiencies in mature spring barley plants. Plant Breed 120:129-132

Górny AG, Garczyński S, Banaszak Z, Ługowska B, Grzesiak S, Bandurska H, Komosa A (2004) Photosynthetic activity and efficiency of gas exchange of the upper leaves in field-grown cultivars of winter wheat under varied nitrogen nutrition. Z Probl Post Nauk Roln 496:61-72

Górny AG, Garczyński S, Banaszak Z, Ługowska B (2006a) Genetic variation in the efficiency of nitrogen utilization and photosynthetic activity of flag leaves among the old and modern germplasm of winter wheat. J Appl Genet 47:231-237

Górny AG, Grzesiak M, Grzesiak S (2006b) Responses of winter wheat cultivars and their hybrids to soil drought and nitrogen defficiency. II. Inheritance of root characters. Z Probl Post Nauk Roln 509:111-124

Habash DZ, Bernard S, Schondelmaier J, Weyen J, Quarrie SA (2007) The genetics of nitrogen use in hexaploid wheat: $N$ utilization, development and yield. Theor Appl Genet 114:403-419 
Hirel B, Bertin P, Quilleré I, Bourdoncle W, Attagnant C, Dellay C, Gouy A, Cadiou S, Retailliau C, Falque M, Gallais A (2001) Towards a better understanding of the genetic and physiological basis for nitrogen use efficiency in maize. Plant Physiol 125:1258-1270

Hirel B, Le Gouis J, Ney B, Gallais A (2007) The challenge of improving nitrogen use efficiency in crop plants: towards a more central role for genetic variability and quantitative genetics within integrated approaches. J Exp Bot 58:2369-2387

Huggins DR, Pan WL (2003) Key indicators for assessing nitrogen use efficiency in cereal-based agroecosystems. J Crop Prod 8:157-185

Jamieson PD, Semenov MA (2000) Modelling nitrogen uptake and redistribution in wheat. Field Crops Res 68:21-29

Kala R, Chudzik H, Dobek A, Kiełczewska H (1994) DGH 1.0- Statistical analysis system for genetic and breeding experiments. Agric Univ, Poznań, Poland

Kichey T, Hirel B, Heumez E, Dubois F, Le Gouis J (2007) Wheat genetic variability for post-anthesis nitrogen absorption and remobilisation revealed by ${ }^{15} \mathrm{~N}$ labelling and correlations with agronomic traits and nitrogen physiological markers. Field Crop Res 102:22-32

Lammerts van Bueren ET, Østergård $\mathrm{H}$, Goldringer I, Scholten O (2008) Plant breeding for organic and sustainable, lowinput agriculture: Dealing with genotype-environment interactions. Proceedings of the EUCARPIA symposium of working group organic plant breeding, 7-9 Nov 2007, Wageningen. Euphytica 2008, doi:10.1007/s10681-0089731-4, pp 1-72

Laperche A, Brancourt-Hulmel M, Heumez E, Gardet O, Le Gouis J (2006a) Estimation of genetic parameters of a DH wheat population grown at different $\mathrm{N}$ stress levels characterized by probe genotypes. Theor Appl Genet 112:797-807

Laperche A, Devienne-Barret F, Maury O, Le Gouis J, Ney B (2006b) A simplified conceptual model of carbon/nitrogen functioning for QTL analysis of winter wheat adaptation to nitrogen deficiency. Theor Appl Genet 113:1131-1146

Laperche A, Brancourt-Hulmel M, Heumez E, Gardet O, Hanocq E, Devienne-Barret F, Le Gouis J (2007) Using genotype $\times$ nitrogen interaction variables to evaluate the QTL involved in wheat tolerance to nitrogen constraints. Theor Appl Genet 115:399-415

Laperche A, Le Gouis J, Hanocq E, Brancourt-Hulmel M (2008) Modelling nitrogen stress with probe genotypes to assess genetic parameters and genetic determinism of winter wheat tolerance to nitrogen constraint. Euphytica 161:259-271

Lawlor DW (2002) Carbon and nitrogen assimilation in relation to yield: mechanisms are the key to understanding production systems. J Exp Bot 53:773-787

Le Gouis J, Pluchard P (1996) Genetic variation for nitrogen use efficiency in winter wheat (Triticum aestivum L.). Euphytica 92:221-224

Le Gouis J, Béghin D, Heumez E, Pluchard P (2000) Genetic differences for nitrogen uptake and nitrogen utilisation efficiencies in winter wheat. Eur J Agron 12:163-173

Le Gouis J, Béghin D, Heumez E, Pluchard P (2002) Diallel analysis of winter wheat at two nitrogen levels. Crop Sci 42:1129-1134
Löschenberger F, Fleck A, Grausgruber G, Hetzendorfer H, Hof G, Lafferty J, Marn M, Neumayer A, Pfaffinger G, Birschitzky J (2008) Breeding for organic agriculture-the example of winter wheat in Austria. Euphytica 163:469-480

Marschner H (1995) Mineral nutrition of higher plants, 2nd edn. Academic Press Inc, London

Martre P, Porter JR, Jamieson PD, Triboï E (2003) Modeling grain nitrogen accumulation and protein composition to understand the sink/source regulations of nitrogen utilization in wheat. Plant Physiol 133:1959-1967

Martre P, Semenov MA, Jamieson PD (2007) Simulation analysis of physiological traits to improve yield, nitrogen use efficiency and grain protein concentration in wheat. In: Spiertz JHJ et al (eds) Scale and complexity in plant systems research. Gene-plant-crop relations. Springer, Dordrecht, The Netherlands, pp 181-201

Medici LO, Pereira MB, Lea PJ, Azevedo RA (2004) Diallel analysis of maize lines with contrasting responses to applied nitrogen. J Agric Sci 142:535-541

Moll RH, Kamprath EJ, Jackson WA (1982) Analysis and interpretation of factors which contribute to efficiency of nitrogen utilization. Agronomy J 74:562-564

Murphy KM, Campbell KG, Lyon SR, Jones SS (2007) Evidence of varietal adaptation to organic farming systems. Field Crop Res 102:172-177

Muurinen S, Slafer GA, Peltonen-Sainio P (2006) Breeding effects on nitrogen use efficiency of spring cereals under northern conditions. Crop Sci 46:561-568

Nowosielski O (1974) Diagnostic methods for fertilization requirements, 2nd ed. (Pol), PWRiL, Warsaw, Poland

Oracka T, Ciepły J, Kozdój J (2000) Genetic variability in mineral elements utilisation efficiency in spring wheat under different mineral element regimes. Plant Breed Seed Sci 40:15-24

Ortiz-Monasterio JI, Sayre KD, Rajaram S, McMahon M (1997) Genetic progress in wheat yield and nitrogen use efficiency under four nitrogen rates. Crop Sci 37:898-904

Phillips SL, Wolfe MS (2005) Evolutionary plant breeding for low input systems. J Agric Sci 143:245-254

Presterl T, Groh S, Landbeck M, Seitz G, Schmidt W, Geiger $\mathrm{HH}$ (2008) Nitrogen uptake and utilization efficiency of European maize hybrids developed under conditions of low and high nitrogen input. Plant Breed 121:480-486

Quarrie SA, Steed A, Calestani C, Semikhodskii A, Lebreton C, Chinoy C, Steele N, Pljevljakusic D, Waterman E, Weyen J, Schondelmaier J, Habash DZ, Farmer P, Saker L, Clarkson DT, Abugalieva A, Yessimbekova M, Turuspekov Y, Abugalieva S, Tuberosa R, Sanguineti MC, Hollington PA, Aragues R, Royo A, Dodig D (2005) A high-density genetic map of hexaploid wheat (Triticum aestivum L.) from the cross Chinese Spring-SQ1 and its use to compare QTLs for grain yield across a range of environments. Theor Appl Genet 110:865-880

Sattelmacher B, Horst WJ, Becker HC (1994) Factors that contribute to genetic variation for nutrient efficiency of crop plants. Z Pflanzenernähr Bodenk 157:215-224

Simmonds NW (1995) The relation between yield and protein in cereal grains. J Sci Food Agric 67:309-315

Singh RK, Chaudhary BD (1979) Biometrical methods in quantitative genetic analysis, 2nd edn. Kalyani Publ, Ludhiana, New Delhi, India 
Sylvester-Bradley R, Kindred DR (2009) Analysing nitrogen responses of cereals to prioritise routes to the improvements of nitrogen use efficiency. J Exp Bot 60:1939-1951

Van Ginkel M, Ortiz-Monasterio JI, Trethowan R, Hernandez E (2001) Methodology for selecting segregating populations for improved N-use efficiency in bread wheat. Euphytica 119:223-230

von Wirén N, Gazzarrini S, Frommer WB (1997) Regulation of mineral nitrogen uptake in plants. Plant Soil 196:191-199
Wolfe MS, Baresel JP, Desclaux D, Goldringer I, Hoad S, Kovacs G, Löschenberger F, Miedaner T, Østergård $H$, Lammerts van Bueren ET (2008) Developments in breeding cereals for organic agriculture. Euphytica 163:323-346

Yildirim M, Bahar B, Genc I, Korkmaz K, Karnez E (2007) Diallel analysis of wheat parents and their $F_{2}$ progenies under medium and low level of available $\mathrm{N}$ in soil. J Plant Nutr 30:937-945 